\title{
Pengembangan Bahan Ajar Multilingual Berbasis Konten dan Konteks Budaya Lokal Etnis Ngada pada Tema Hidup Bersih dan Sehat untuk Siswa Kelas 2 Sekolah Dasar
}

\author{
Genoveva Dhey ${ }^{1}$, Dek Ngurah Laba Laksana ${ }^{2}$, Maria Patrisia Wau ${ }^{3}$ \\ ${ }^{1-3}$ Program Studi Pendidikan Guru Sekolah Dasar, STKIP Citra Bakti Ngada, NTT, Indonesia
}

* Genoveva Dhey; Program Studi Pendidikan Guru Sekolah Dasar, STKIP Citra Bakti, Ngada, NTT; Email:genovevadhey18@gmail.com.
Abstrak: Penelitian ini bertujuan untuk mengembangkan dan menghasilkan bahan ajar multilingual berbasis konten dan konteks budaya lokal etnis Ngada tema Hidup Bersih dan Sehat untuk siswa kelas 2 Sekolah Dasar. Bahan ajar ini tebatas pada pengembangan tiga bahasa yaitu bahasa Indonesia, bahasa daerah Bajawa dan bahasa Inggris. Subjek uji coba dalam penelitian ini antara lain guru kelas 2 SDN Sobo sebagai ahli materi/isi, kepala sekolah dan guru SMP Citra Bakti sebagai ahli Bahasa Indonesia dan Bahasa Inggris, Bapak Johanes Mopa sebagai ahli Bahasa Daerah dan Dr. Aan Nurfahrudianto. Hasil penelitian pengembangan bahan ajar multilingual berbasis konten dan konteks budaya lokal etnis Ngada ini dikembangakan menggunakan model ADDIE. (1) Uji coba ahli konten/materi dengan nilai rata-rata 4.2, (2) Uji coba untuk ahli bahasa Indonesia dengan nilai rata-rata 3.7, (3) Uji coba untuk ahli bahasa Daerah dengan nilai rata-rata 3.4, (4) Uji coba untuk ahli bahasa Inggris ada dengan nilai rata-rata 4.2, (5) Uji coba ahli desain ada pada kategori "sangat baik" dengan rata-rata 4.4. Dari hasil pengujian kepada beberapa ahli di atas maka dapat disimpulkan bahan ajar multilingual berbasis konten dan konteks budaya lokal etnis Ngada tema Hidup Bersih dan Sehat untuk siswa kelas 2 sekolah dasar layak dan siap digunakan.

Kata Kunci: Bahan Ajar, Budaya Lokal Etnis Ngada, Pengembangan.

Abstract: This study aims to develop and produce multilingual teaching materials focused On Content and local cultural contetxt of the Ngada ethnic with the theme of clean and Healthy Living for 2 st grade. This teaching materials is limited to the development of three languages, namely Indonesian Language, Bajawa Language and English Language. In this study sources data were obtained from teacher at SDN Sobo as materials/content expert, the principal and teacher of SMP Citra Bakti an Indonesia Language and English expert, Mr Johanes Mopa as an expert on Regional Languages and Dr.Aan Nurfarudianto as design expert. While the object being studied is focused On Content and Background of Ngada culture with the theme of clean and Healthy Living for 2st grade. The teaching materials are developed using the Addie model. (1) Test for matrials/content experts with an average of 4.2, (2) The test for Indonesian language experts with an average of 3.7. (3) The test for local language with an average of 3.4. (4) the test for English language experts with an average of 4.2, (5) The design experts with an average of 4.4. From the result of testing to several experts above.Thus,multilingual teaching materials focused On Content and local cultural contetxt of the Ngada ethnic with the theme of clean and Healthy Living for 2 st grade. are feasible and ready to be us.

Keywords: Development, Teaching Materials, Local Culture of the Ngada Ethnic. 


\section{PENDAHULUAN}

Mutu pendidikan yang rendah merupakan salah satu masalah yang dialami dalam dunia pendidikan. Rendahnya kualitas pendidikan dapat dipengaruhi oleh bahan ajar dan proses pembelajaran yang belum efektif. Berdasarkan hal tersebut, maka guru harus memperhatikan strategi belajar mengajar sehinggah tercipta situasi belajar yang efektif dan efisien sesuai dengan materi yang diajarkan serta memperhatikan karakteristik peserta didik dalam proses pembelajaran.

Kemampuan mengembangkan bahan ajar merupakan perwujutan dari salah satu kompetensi yang harus dimiliki seorang guru yaitu kompetensi pedagogik. Sejalan dengan pendapat diatas dalam Undang-Undang Sisdiknas No. 20 Tahun 2003 menerangkan dalam kegiatan belajar mengajar guru harus menyiapkan bahan ajar yang kontekstual (Depdiknas, 2003). Akan tetapi pada kenyataan yang terjadi dalam proses pembelajaran guru belum mampu membuat bahan ajar yang kontekstual. Ketidakmampuan tersebut membuat guru terpaku pada bahan ajar yang disiapkan pemerintah yang belum sesuai dengan lingkungan nyata siswa. Sehinggah dalam proses pembelajaran akan membuat siswa kurang mengerti dengan materi yang dijelaskan guru. Untuk menarik perhatian peserta didik dalam pembelajaran maka, guru harus merancang bahan ajar yang sesuai budaya setempat.

Unsur budaya lokal ini cocok dimasukan kedalam bahan ajar siswa, khususnya siswa di sekolah dasar. Namun, bahan ajar yang sekarang digunakan disekolah- sekolah masih menggunakan bahan ajar cetak yang disediakan oleh pemerintah yang mungkin kurang mengedepankan unsur budaya lokal masyarakat setempat. Sardjiyo dan Pannen (2005; Riwu, Laksana, dan Dhiu, 2018) menyatakan pelajaran berbasis budaya merupakan strategi penciptaan lingkungan belajar dan perancangan pengalaman belajar yang mengintegrasikan budaya sebagai bagian dari proses pembelajaran.

Untuk itu diperlukan bahan ajar yang mengintegrasikan budaya lokal agar dalam pembelajaran guru tidak mengalami kesulitan dalam memberikan penjelasan serta contoh yang nyata, sehinggah dapat menciptakan pembelajaran yang bermakna (Samri, Rewo, dan Laksana, 2020).

Menurut Mulyasa (2006) mengemukakan bahwa bahan ajar merupakan salah satu bagian dari sumber ajar yang dapat diartikan sesuatu yang yang mengandung pesan pembelajaran. Baik yang bersifat khusus maupun yang bersifat umum yang dapat di manfaatkan untuk kepentingan pembelajaran.

Salah satu cara yang dilakukan untuk mengatasi permasalahan di atas peneliti ingin menghasilkan bahan ajar multilingual. Bahan ajar multilingual merupakan bahan ajar yang mengintegrasikan tiga bahasa. Bahasa yang digunakan adalah bahasa Indonesia, sebagai bahasa nasional, bahasa daerah sebagai bahasa penunjang juga sebagai perwujutan kearifan lokal, dan bahasa inggris sebagai bahasa ketiga dan sudah digunakan secara global.

Berdasarkan masalah tersebut, terdapat dua permasalahan yang dikaji dalam tulisan ini, permasalahan pertama adalah apakah dapat dihasilkan bahan ajar multilingual berbasis konten dan konteks budaya lokal etnis Ngada pada tema hidup bersih dan sehat yang selaras dengan karakter siswa sekolah dasar? Permasalahan yang kedua adalah bagaimana kualitas hasil uji coba produk pengembangan bahan ajar multilingual berbasis konten dan konteks budaya lokal etnis Ngada untuk siswa sekolah dasar? Adapun tujuan dalam penulisan ini adalah menghasilkan bahan ajar yang terintegrasi konten dan konteks budaya lokal etnis Ngada serta kualitas bahan ajar yang dihasilkan.

\section{Metode Penelitian}

Jenis penelitian dalam penelitian ini yaitu penelitian pengembangan. Pengembangan perangkat bahan ajar multilingual ini menggunakan model pengembangan ADDIE. Prosedur pengembangan model ADDIE terdiri atas lima tahapan (Anglada, 2007). Tahap penjelasan dari model pengembangan ADDIE yang akan peneliti terapkan yaitu sebagai berikut. 1) Analyze (Analisis); Tahap analisis yang dilakukan peneliti mencakup tiga hal penting yaitu analisis kebutuhan, analisis kurikulum, dan analisis karakteristik peserta didik kelas II Sekolah Dasar. 2) Design (Perancangan), pada tahap ini mulai dirancang bahan ajar yang akan dikembangkan sesuai dengan hasil analisis yang dilakukan sebelumnya. 3) Development (Pengembangan). Tahap development merupakan tahap realisasi produk. Dalam tahap ini pengembangan bahan ajar dilakukan sesuai dengan perancangan. 4) Implementation (Implementasi). Tahap implementation hanya sampai pada validator ahli yang direkomendasikan untuk menilai produk bahan ajar yang sudah dikembangkan. 5) Evaluation (Evaluasi). Pada tahap evaluasi ini, peneliti melakuan revisi yang terakhir kalinya terhadap bahan ajar yang dikembangkan atas dasar 
informasi yang diperoleh dari instrumen penilaian yang dinilai oleh setiap validator/ahli. Produk yang dihasilkan berupa bahan ajar multilingual berbasis konten dan konteks budaya lokal etnis Ngada pada tema hidup bersih dan sehat untuk kelas II SD. Uji coba produk ini menggunakan instrumen dalam bentuk angket yang telah disusun. Instrumen yang berupa angket dinilai oleh ahli konten/materi pada kelayakan isi dari materi ajar, ahli desain pada kelayakan desain produk bahan ajar yang dikembangkan, ahli bahasa pada kesesuaian penggunaan bahasa. Subjek uji coba dalam penelitian ini antara lain: (1) guru kelas II SD sebagai ahli konten/materi yang diambil dari SDN Sobo, (2) Kepala Sekolah dan guru SMP Citra Bakti sebagai ahli bahasa Indonesia dan bahasa Inggris, (3) seorang tokoh penulis buku bahasa daerah Bajawa sebagai ahli bahasa daerah. (4) Bapak Dr. Aan Nurfarudianto sebagai ahli desain. Data yang diperoleh didalam penelitian ini yaitu: (1) data isi dari materi ajar dalam tema merawat hewan dan tumbuhan yang dapat diintegrasikan dengan konten dan konteks budaya lokal etnis Ngada, (2) data karakteristik budaya lokal etnis Ngada sebagai konten dan konteks terhadap bahan ajar multilingual pada hidup bersih dan sehat, (3) data kualitas bahan ajar multilingual ini akan dilihat dari isi, penyajian, kebahasaan dan kelayakan penggunaan. Metode yang diterapkan selama proses mengumpulkan data yaitu: 1) metode observasi. 2) metode wawancara. 3) metode pencatatan dokumen, Instrumen pengumpulan data dalam penelitian pengembangan bahan ajar multilingual ini adalah berbentuk angket yang berpatok pada penilaian Badan Standarisasi Nasional Pendidikan (BSNP), di antaranya yaitu komponen isi dan kegrafikan.

Data yang sudah dikumpulkan dari hasil penelitian ini dianalisis secara deskriptif sebagai berikut: 1) Data tentang kualitas bahan ajar multilingual hasil review ahli dianalisis secara deskriptif untuk menganalisis data hasil review ahli materi, ahli desain pembelajaran dan ahli bahasa. Teknik analisis data ini dilakukan dengan mengelompokan informasi dari data kualitatif yang berupa saran, kritik, masukan, dan tanggapan yang terdapat pada angket. 2) Data mengenai kualitas bahan ajar multilingual berisi budaya lokal hasil uji coba produk dianalisis melalui konversi skor yang diperoleh dari lembar kuisioner. Pengubahan hasil penilaian dari setiap Ahli, berawal dari bentuk kualitatif ke bentuk kuantitatif dengan menggunakan skala 5 sebagai berikut: skor 1 Sangat Kurang (SK), skor 2 Kurang (K), skor 3 Cukup (C), skor 4 Baik (B), dan skor 5 Sangat Baik (SB). Produk yang dikembangkan dikatakan memiliki derajat validitas atau kualitas yang baik jika minimal kriteria validitas yang dicapai adalah baik.

\section{HASIL DAN PEMBAHASAN \\ Hasil Penelitian}

Pengembangan produk bahan ajar yang dikembangkan ini menggunakan model pengembangan ADDIE.

\section{Tahap Analyze}

Pada tahap analisis ini, salah satu sub bagian yang dianalisis oleh peneliti yaitu analisis terhadap kurikulum. Kurikulum dirancang dengan memperhatikan karakteristik kurikulum yang sementara dijalankan di sekolah-sekolah seperti sekarang ini. Kemudian peneliti melakukan analisis kebutuhan. Berdasarkan hasil wawancara juga diperoleh hasil bahwa jenis bahan ajar yang digunakan di sekolah adalah bahan ajar cetak yang disediakan oleh pemerintah dan merupakan hasil dari suatu penerbit. Setelah masalah dianalisis dan solusinya ditemukan, maka langkah berikutnya yaitu peneliti menganalisis pemetaan kompetensi dasar di setiap sub tema dan kompetensi dasar di setiap pembelajaran yang dapat mencapai tujuan pembelajaran. Kompetensi dasar yang dianalisis oleh peneliti adalah kompetensi dasar kelas 2 pada tema "hidup bersih dan sehat".

\section{Tahap Design}

Tahap desain atau perancangan dalam menyusun bahan ajar ini diawali dengan menentukan hal-hal pokok yang diperlukan dalam bahan ajar seperti pemetaan Kompetensi Dasar di setiap sub tema dan pembelajaran, kerangka bahan ajar, dan mengumpulkan bahan acuan yang dimanfaatkan dalam pengembangan materi dari bahan ajar. Peneliti juga mengumpulkan gambargambar yang berkaitan dengan materi ajar untuk dimasukan dalam bahan ajar yang dikembangkan.

\section{Tahap Development}

Tahap pengembangan merupakan tahap realisasi produk. Pada tahap ini peneliti melakukan pengembangan produk bahan ajar multilingual dengan melalui beberapa tahap yaitu: (1) melakukan pengembangan produk bahasa Indonesia. Peneliti menyusun buku bahasa Indonesia dengan memasukan materi ajar berbasis konten dan konteks budaya lokal etnis Ngada yang dilengkapi dengan gambar sebagai komponen penjelas dari materi ajar, keterangan gambar beserta sumber gambar. Pada pengembangan tahap ini peneliti melakukan pengembangan bahan ajar berpatok pada 
pedoman buku guru dan buku siswa tema 4 untuk siswa SD kelas II revisi 2017. (2) melakukan pengembangan bahasa daerah. Pada tahap ini peneliti menerjemahkan buku bahasa Indonesia yang sudah disusun diterjemahkan ke dalam bentuk bahasa daerah Bajawa. (3) melakukan pengembangan produk bahasa Inggris. Pada tahap ini peneliti menerjemahkan bahan ajar bahasa Indonesia yang sudah disusun dan diterjemahkan ke dalam bentuk bahasa Inggris. Hasil pengembangan bahan ajar multiligual berbasis konten dan konteks budaya lokal etnis Ngada yaitu sebagai berikut. (1) Halaman judul (Cover) merupakan tampilan dari buku tematik multilingual yang dikembangkan, baik tampilan cover depan maupun tampilan cover belakang. (2) Kata pengantar memuat ucapan syukur penulis kepada Tuhan Yang Maha Esa atas semua berkat dan bimbingan-Nya kepada penulis, semasa penulis. (3) Tentang bahan ajar multilingual ini merupakan panduan yang dirancang sangat sederhana dan bertujuan untuk menyampaikan kepada guru dan siswa terkait komponenkomponen yang tercantum dalam isi bahan ajar. (4) Daftar isi dibuat dengan tujuan mempermudahkan orang yang membaca atau pengguna produk untuk membuka setiap sub tema dan halaman yang bakal mereka pelajari. (5) Sub tema dibuat dengan tujuan memberikan gambaran awal dalam bentuk gambar dan tulisan seperti "cara hidup bersih dan sehat di rumah" untuk bagaimana mempelajari semua materi yang tercantum pada sub tema. (6) Kompetensi dasar yang dipetakan dalam bahan ajar multilingual berbasis konten dan konteks budaya lokal etnis Ngada ini adalah tema 4 yaitu "hidup bersih dan sehat" untuk siswa kelas II SD. Pemetaan KD subtema 1 yang terkandung pada bahan ajar multilingual ini memuat tentang sejumlah mata pelajaran yang menjadi fokus pembelajaran misalnya Bahasa Indonesia, SBdP, PPKn dan Matematika. (7) Materi yang terdapat dalam bahan ajar multilingual ini yaitu materi tema 4 yaitu "hidup bersih dan sehat" untuk siswa kelas II SD yang dipadukan dengan konten dan konteks budaya lokal etnis Ngada. (8) Daftar pustaka berisi daftar referensi dan sumber-sumber yang membantu proses penyelesaian pengembangan bahan ajar multilingual ini.

Pada tahap pengembangan ini juga, bahan ajar yang telah jadi divalidasi oleh dosen dan guru ahli, (4) Implementation. Pada tahap implementasi ini, peneliti melaksanakan uji coba produk pengembangan bahan ajar multilingual berbasis konten dan konteks budaya lokal etnis
Ngada terhadap ahli konten/materi, ahli bahasa dan ahli desain bahan ajar dan (5) Evaluation. Tahap evaluasi yaitu tahap yang dilakukan peneliti untuk merevisi setiap tahap-tahap pengembangan lainnya.

\section{1) Revisi Tahap Analyze}

Peneliti menganalisis kompetensi Dasar kelas II Sekolah Dasar pada tema "Hidup Bersih dan sehat". Setelah menganalisi KD, peneliti melakukan revisi berdasarkan komentar pembimbing I dan II. Hasil revisi pada tahap ini adalah menciptakan lagu daerah berdasarkan bunyi pada kompetensi dasar SBdP.

\section{2) Revisi Tahap Design}

peneliti menyusun draf bahan ajar multilingual berbasis konten dan konteks budaya lokal etnis Ngada. Berdasarkan hasil analisis yang dilaksanakan pada tahap sebelumnya. Komentar dan saran pembimbing I dan II dalam tahap ini yaitu gambar-gambar yang terdapat dalam bahan ajar yang dikembangkan harus bersifat kontekstual agar siswa mampu memahami materi pelajaran dengan baik.

3) Revisi Tahap Development, Revisi tahap ini lebih kepada hasil uji coba pertama produk pengembangan ke beberapa validator/ahli. Hasil revisi produk bahan ajar multilingual berdasarkan komentar/masukan maupun saran dari masingmasing validator/ahli dapat kita lihat pada penjelasan berikut. (1) Revisi Hasil Uji Coba Ahli Konten/Materi. Penilaian yang diberikan oleh ahli konten/materi terhadap produk bahan ajar multilingual yang dikembangkan pada tahap ini yaitu, ahli konten/materi lebih menekankan kepada aspek kesesuaian materi dengan kompetensi inti dan kompetensi dasar. (2) Revisi Hasil Uji Coba Ahli Bahasa. Penilaian yang diberikan oleh ahli bahasa terhadap produk bahan ajar multilingual yaitu sebagai berikut: (1) revisi hasil uji coba ahli bahasa Indonesia. Penilaian yang diberikan oleh ahli bahasa Indonesia yaitu penggunaan huruf kapital, warna pada tulisan, dan penggalan kata pada kalimat, penggunaan tanda baca yang belum sesuai, penulisan kalimat yang mudah dimengerti oleh peserta didik kelas II SD, (2) revisi hasil uji coba ahli bahasa daerah. yaitu ketepatan penulisan bahasa daerah Bajawa yang belum pas serta pentingnya penggunaan tanda baca yang terdapat pada beberapa kata bahasa daerah Bajawa, (3) revisi hasil uji coba ahli bahasa Inggris. Penilaian hasil uji coba bahasa Inggris yaitu penggunaan kata dan kalimat yang belum sesuai dengan grammar. (3) Revisi Hasil Uji Coba Ahli Desain Bahan Ajar. Penilaian yang diberikan oleh ahli desain pembelajaran terhadap 
produk bahan ajar multilingual yang dikembangkan pada tahap ini yaitu, ahli desain bahan ajar memberikan komentar penempatan gambar atau tabel harus dibuat simetris, memberikan materi dan contoh selalu diawali dengan cerita atau kasus yang konkrit. Produk hasil pengembangan disajikan pada Gambar 1 .

\section{Pembahasan}

Berdasarkan uraian hasil penelitian di atas, maka berikut hasil produk bahan ajar yang dikembangkan dan tabel rekapitulasi hasil uji coba produk dari setiap ahli dijabarkan dalam Tabel 1.

Tabel 1. Data Hasil Uji Coba Produk yang Dikembangkan dari Setiap Ahli

\begin{tabular}{|l|l|l|l|l|}
\hline No & \multicolumn{1}{|c|}{$\begin{array}{c}\text { Ahli yang } \\
\text { menilai }\end{array}$} & $\begin{array}{c}\text { Jumlah } \\
\text { skor }\end{array}$ & $\begin{array}{c}\text { Rata- } \\
\text { rata } \\
\text { skor }\end{array}$ & Kriteria \\
\hline 1 & $\begin{array}{l}\text { Ahli } \\
\text { konten/materi }\end{array}$ & 77 & 4,2 & $\begin{array}{l}\text { Sangat } \\
\text { baik }\end{array}$ \\
\hline 2 & $\begin{array}{l}\text { Ahli bahasa } \\
\text { Indonesia }\end{array}$ & 40 & 3,7 & Baik \\
\hline 3 & $\begin{array}{l}\text { Ahli bahasa } \\
\text { daerah }\end{array}$ & 41 & 3,4 & Baik \\
\hline 4 & $\begin{array}{l}\text { Ahli bahasa } \\
\text { Inggris }\end{array}$ & 55 & 4,2 & $\begin{array}{l}\text { Sangat } \\
\text { Baik }\end{array}$ \\
\hline 5 & $\begin{array}{l}\text { Ahli desain } \\
\text { bahan ajar }\end{array}$ & 49 & 4,4 & $\begin{array}{l}\text { Sangat } \\
\text { baik }\end{array}$ \\
\hline
\end{tabular}

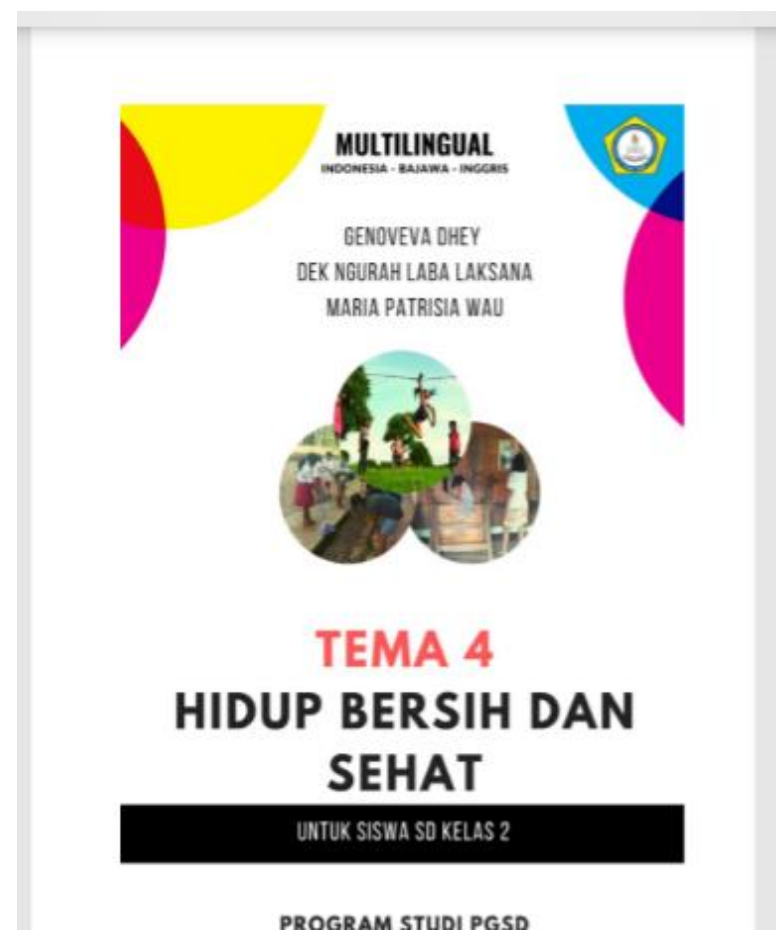

PROGRAM STUDI PGSD

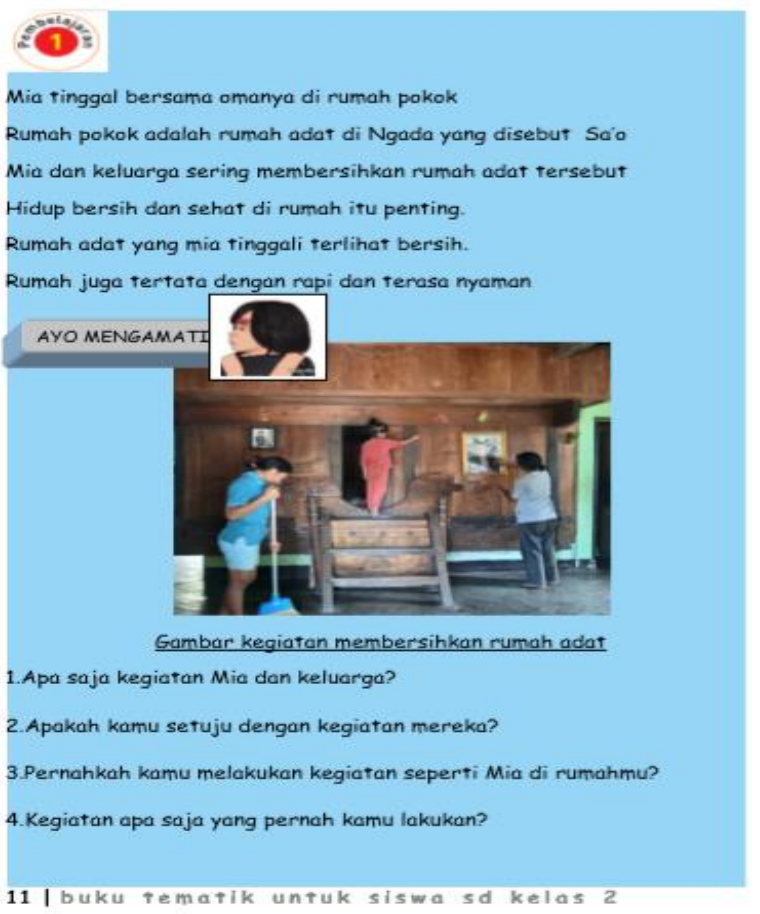

Gambar 1. Produk Hasil Pengembangan, halaman depan dan salah satu bagian isi buku

Pengembangan produk bahan ajar berbasis budaya lokal telah berhasil dikembangkan dan layak sebagai bahan ajar. Pengembangan ini ini sejalan dengan hasil penelitian yang dilakukan oleh Wini, Laksana, dan Awe (2020), hasil penelitian pengembangan ini membuktikan bahwa, bahan ajar yang dikembangkan Maria klarita mutiara wini, dkk (2020) pada kategori "baik" dan layak digunakan. Lebih lanjut, Awe dan Moma (2021) menemukan bahwa bahwa, bahan ajar yang dikembangkan pada kategori "baik" dan layak digunakan. Selanjutnya, Remba, Noge, dan Wau (2021) membuktikan bahwa, bahan ajar yang dikembangkan pada kategori "baik" dan layak digunakan.

Peneltian penelitian lai juga menunjukkan hasil yang sama. Hasil penelitian menyebutkan bahwa bahan ajar yang dikembangkan berada pada kategori sangat baik dan sangat bisa dimanfaatkan oleh sekolah-sekolah yang ada di kabupaten Ngada (Lawe, dkk., 2021). Hasil penelitian Laksana, dkk (2016) tentang "Pengembangan Bahan Ajar Tematik SD Kelas IV Berbasis Kearifan Lokal Masyarakat Ngada". Hasil penelitian dari lembar kuisioner membuktikan bahwa, bahan ajar yang dikembangkan berada pada kategori sangat baik dan sangat bisa dimanfaatkan oleh sekolahsekolah yang ada dikabupaten Ngada khususnya daerah Bajawa siswa SD kelas IV.

Penelitian yang dilakukan oleh Laksana 
(2018), dengan judul "Konten Dan Konteks Budaya Lokal Ngada Sebagai Bahan Ajar Tematik Di Sekolah Dasar". Hasil analisis data diperoleh bahwa konten dan konteks budaya lokal Ngada sebagai bahan ajar tematik di Sekolah Dasar mendapat kriteria "sangat baik" dan layak untuk digunakan oleh sekolah-sekolah yang ada di kabupaten Ngada.

Sementara itu, penelitian Seso, Laksana, dan Kaka, (2021), dengan judul "Pengembangan Desain Pembelajaran Tematik tema Berbagai pekerjaan media Lks Budaya Lokal Ngada Berorientasi Model Pembelajaran Berbasis Masalah Untuk Siswa Kelas IV Sekolah Dasar" Hasil penelitian dari lembar kuisioner membuktikan bahwa, bahan ajar yang dikembangkan berada pada kategori sangat baik dan layak digunakan.

Penelitian yang dilakukan oleh Laksana, Lawe, dan Ripo (2020) yang berjudul "Lembar Kerja Siswa Berbasis Budaya Lokal Ngada Untuk Pembelajaran Tematik Siswa Sekolah Dasar" Hasil penelitian dari lembar kuisioner ini, membuktikan bahwa lembar kerja siswa yang dikembangkan sangat baik dan layak digunakan.

Penelitian yang dilakukan oleh Laksana, (2017) yang berjudul "Pengembangan Multimedia Pembelajaran Tematik Sekolah Dasar Berbasis Budaya Lokal Masyarakat Flores" Hasil penelitian dari lembar kuisioner, membuktikan bahwa pengembangan yang dilakukan ada pada kategori sangat baik dan layak digunakan.

Berdasarkan data perolehan uji coba di atas telah menjawab rumusan masalah dalam penelitian ini yaitu (1) Peneliti berhasil mengembangkan bahan ajar cetak multilingual berbasis konten dan konteks budaya lokal etnis Ngada pada tema hidup bersih dan sehat di serta bahan ajar yang dikembangkan ini telah sesuai dengan karakteristik siswa Sekolah Dasar kelas II di Kabupaten Ngada khususnya daerah Bajawa karena bahan ajar yang dikembangkan berbasis konten dan konteks budaya lokal etnis Ngada, (2) peneliti berhasil mengembangkan bahan ajar multilingual dengan perolehan kriteria validasi hasil uji coba produk sangat baik.

\section{KESIMPULAN DAN SARAN Kesimpulan}

Adapun kesimpulan dari penelitian ini adalah hasil pengembangan bahan ajar multilingual berbasis konten dan konteks budaya lokal etnis Ngada tema 4 hidup bersih dan sehat untuk siswa kelas 2 sekolah dasar terdiri dari cover, kata pengantar, daftar isi, subtema 1 (pembelajaran 1-6), subtema 2 (pembelajaran 1-
6), subtema 3 (pembelajaran 1-6), subtema 4 (pembelajaran 1-6), daftar pustaka. Bahan ajar multilingual berbasis budaya lokal etnis Ngada ini, kemudian dilakukan uji coba kepada ahli materi/isi, ahli bahasa Indonesia,ahli bahasa daerah, dan ahli desain. Hasil uji coba diperoleh dengan cara penilaian kuisioner, dapat dikategorikan bahwa kualitas bahan ajar multilingual berbasis konten dan konteks budaya lokal etnis Ngada berdasarkan uji coba ahli materi/ isi ada pada kategori" sangat baik", Uji coba untuk ahli bahasa Indonesia berada pada kategori "baik", uji coba bahasa daerah pada kategori "baik", Uji coba untuk bahasa Inggris berada pada kategori "sangat baik", dan uji coba untuk ahli desain pada kategori "sangat baik".

\section{Saran}

Beberapa saran yang peneliti berikan yaitu sebagai berikut. 1) Guru diharapkan untuk dapat memanfaatkan bahan ajar multilingual yang sudah dikembangkan peneliti, guru selalu diharapkan untuk bisa mengembangkan bahan ajar lainnya yang berbasis budaya lokal etnis Ngada secara kontekstual sesuai dengan tuntutan Undang-Undang yang berlaku. 2) Siswa hendaknya belajar memahami materi secara luas dan mendalam berdasarkan pendekatan budaya lokal dengan cara belajar tiga bahasa/multilingual (Indonesia, Daerah, dan Inggris). 3) Lembaga satuan pendidikan Sekolah Dasar diharapkan untuk menyediakan atau memiliki bahan ajar seperti yang dikembangkan peneliti bermanfaat untuk membantu guru dan siswa belajar secara efektif dan menyenangkan berdasarkan pendekatan budaya lokal etnis Ngada yang kontekstual.

\section{Daftar Pustaka}

Anglada, D. (2007). An introduction to instructional design: utilizing a basic design model. http://www.pace.sdu/ctlt/newsletter. diakses tanggal 23Juni 2019.

Awe, E.Y, \& Moma, A. (2021). Pengembangan bahan ajar multilingual berbasis konten dan konteks budaya lokal etnis ngada pada tema kegiatanku untuk siswa sekolah dasar. Jurnal Ilmiah Pendidikan Citra Bakti,8(1), 53-67. https://doi.org/10.38048/jipcb.v8i1.107

Laksana D.N.L., Kurniawan P.A. W, \& Niftalia, I. (2016). Pengembangan bahan ajar tematik SD kelas IV berbasis kearifan lokal masyarakat Ngada. Jurnal Ilmiah Pendidikan Citra Bakti. 3(1), 1-10. Tersedia melalui 
http://www.ejournal.citrabakti.ac.id/inde x.php/jipcb/article/view/74/0

Laksana, D. N. L,\& Widiastika I. G. (2017). Pengembangan multimedia pembelajaran tematik Sekolah Dasar berbasis budaya lokal masyarakat flores. JurnalPendidikan Dasar Nusantara,2(2), 151-162.

Tersediamelaluihttps://ojs.unpkediri.ac.i d/index.php/pgsd/article/view/549

Laksana, D.N.L., Lawe, Y.U., Ripo, F., Bolo, M.O., \& Dua, T.D. (2020). Lembar kerja siswa berbasis budaya lokal Ngada untuk pembelajaran tematik siswa sekolah dasar. Jurnal Pendidikan Dasar Nusantara, 5 (2), 227-241. https://doi.org/10.29407/jpdn.v5i2.13903

Lawe, Y.U., Noge, M.D., Rato, K.P.D., \& Novaliendry, D. (2021). Creation of multilingual teaching materials focused on content and background of Ngada culture for primary 1st grade. Turkish Journal of Computer and Mathematics Education, 12 (2), 3110-3118. https://doi.org/10.17762/turcomat.v12i2. 2355

Muga, W., \& Laksana D.N.L. (2017). Pengembangan bahan ajar elektronik berbasis model problem based learning dengan menggunakan model dick and carey. Journal of Education Technology, 1(4), 260-264. http://dx.doi.org/10.23887/jet.v1i4.12863

Mulyasa. 2006. Kurikulum tingkat satuan pendidikan.

Bandung: RemajaRosdakarya.

Pare, K, Wau, M.P, \& Lawe, Y.U. (2021). Penggunaan bahan ajar elektronik multimedia berbasis budaya lokal ngada untuk meningkatkan hasil belajar tematik tema indahnya keberagaman di negeriku pada siswa kelas IV SDK Olabolo Kecamatan Golewa Kabupaten Ngada. Jurnal Citra Pendidikan, 1(3), 388-396. Tersedia melalui https://jurnalilmiahcitrabakti.ac.id/jil/ind ex.php/jcp/article/view/188

Remba, V., Noge, M.D., Wau, M.P. (2021). Pengembangan bahan ajar multilingual berbasis konten dan konteks budaya lokal etnis ngada pada tema peristiwa alam untuk siswa kelas 1 sekolah dasar, Jurnal Citra Pendidikan, 1(1), 125-135. Tersedia melalui https://jurnalilmiahcitrabakti.ac.id/jil/ind ex.php/jcp/article/view/154

Riwu, I. U, Laksana, D.N.L, \& Dhiu, K.D. (2018). Pengembangan bahan ajar elektronik bermuatan multimedia pada tema peduli terhadap makhluk hidup untuk siswa sekolah dasar kelas IV di Kabupaten Ngada. Journal of Education Technology, $2 \quad$ (2), 56-64. http://dx.doi.org/10.23887/jet.v2i2.16182

Samri, F., Rewo, J.M., \& Laksana, D.N.L. (2020). Electronic thematic teaching multimedia with local culture based materials and its effect on conceptual mastery of primary school students. European Journal of Education Studies, 7 (12), 625-641. http://dx.doi.org/10.46827/ejes.v7i12.34 74

Sardjiyo dan Pannen, P. 2005. Pembelajaran Berbasis Budaya: Model Inovasi Pembelajaran dan 